\title{
APLIKASI REKAM MEDIS PADA PUSKESMAS TALANG TINGGI
}

\author{
Niska Ramadani ${ }^{1,}$ Fadlul Amdhi Yul ${ }^{2}$ \\ Rekam Medis dan Informasi Kesehatan \\ Email : niskaramadani88@gmail.com
}

\begin{abstract}
ABSTRACK
Information technology is currently growing fast, which allows users to receive information quickly. Users needs is different, such as communication, education, business, entertainment, economy, health and others. One example of its users in the health sector is the medical records information system. Medical record is a collection of facts or evidence of a patient's condition, past and present medical history and treatment written by the health professionals that provides patient care.

The objective to be achieved in this research is to make a medical record application of patients at Puskesmas Talang Tinggi using programming language Visual Basic 6.0

The research method used in this research is from conventional system to computerized system with the stages is old system analysis, new system analysis, system design, system implementation and system test.

The software used in making this application is visual basic and using microsoft access database. The results of the report in the show using crystal report.
\end{abstract}

Keywords: Information System, Medical Record, Visual Basic 6.

\begin{abstract}
ABSTRAK
Teknologi informasi saat ini sangat cepat berkembang, yaitu memudahkan pengguna untuk menerima informasi dengan cepat. Adapun kebutuhan penggunanya dalam bentuk bidang yang berbeda, seperti komunikasi, pendidikan, bisnis, hiburan, ekonomi, kesehatan dan lain-lain. Salah satu contoh penggunanya dalam bidang kesehatan adalah sistem informasi pencatatan rekam medis. Rekam medis adalah kumpulan dari fakta-fakta atau bukti keadaan pasien, riwayat penyakit dan pengobatan masa lalu serta saat ini yang ditulis oleh profesi kesehatan yang memberikan pelayanan pada pasien.

Tujuan yang hendak dicapai dalam penelitian ini adalah untuk adalah untuk membuat aplikasi rekam medis pasien pada puskesmas talang tinggi menggunakan bahasa pemrograman Visual Basic 6.0

Metode penelitian yang digunakan dalam penelitian ini adalah dari sistem konvensional menjadi sistem komputer dengan tahapannya adalah analisis sistem lama, analisis sistem baru, perancangan sistem, implementasi sistem dan ujicoba sistem.

Perangkat lunak yang digunakan dalam pembuatan aplikasi ini adalah menggunakan visual basic dan menggunakan database microsoft access. Hasil laporan yang di tampilkan menggunakan crystal report.
\end{abstract}

Kata Kunci : Sistem Informasi, Rekam Medis, Visual Basic 6.0

\section{PENDAHULUAN}

Teknologi informasi saat ini sangat cepat berkembang, yaitu memudahkan pengguna untuk menerima informasi dengan cepat. Adapun kebutuhan penggunanya dalam bentuk bidang yang berbeda, seperti komunikasi, pendidikan, bisnis, hiburan, ekonomi, kesehatan dan lain-lain. Salah satu contoh penggunanya dalam bidang kesehatan adalah sistem informasi pencatatan rekam 
medis. Dalam penjelasan pasal 46 ayat (1) UU Praktik kedokteran yang dimaksud dengan rekam medis adalah berkas yang berisi catatan dan dokumen tentang identitas pasien, pemeriksaan pengobatan, tindakan dan pelayanan lain yang telah diberikan kepada Paisen pada sarana pelayanan kesehatan. Rekam medis ini yang nantinya akan digunakan oleh petugas medis untuk melihat dan menambah catatan kesehatan pasien yang ditangani.

Hal serupa juga dapat terjadi dalam bidang kesehatan. Salah satunya yaitu dalam hal layanan kesehatan di dalam sebuah puskesmas talang tinggi. Puskesmas memiliki peranan penting sebagai salah satu penyedia jasa layanan kesehatan di lingkungan masyarakat, khususnya untuk masyarakat kalangan menengah ke bawah. Dengan diterapkannya proses aplikasi layanan kesehatan secara terkomputerisasi, maka pekerjaan-pekerjaan pengelolaan data dapat dilakukan lebih efektif dan efisien.

Proses pendaftaran pasien baru, masih dilakukan secara manual yaitu dengan menulis data pasien baru ke dalam sebuah buku yang disebut daftar kunjungan pasien, kemudian membuat kartu berobat dan kartu rekam medik dengan menuliskannya pada selembar kertas yang dilakukan oleh petugas bagian administrasi. Dokter / bidan akan menuliskan hasil pemeriksaan pada kartu rekam medis se bagai catatan riwayat pemeriksaan pasien.

Oleh karena itu dibutuhkan sistem informasi pelayanan kesehatan pada puskesmas secara komputerisasi.

\section{TUJUAN PENELITIAN}

Tujuan penelitian ini adalah Untuk merancang sistem informasi rekam medis pada puskesmas Talang Tinggi dengan menggunakan bahasa pemrograman Visual Baic 6.0.

\section{RUMUSAN MASALAH}

Dari uraian yang telah disampaikan pada latar belakang diatas, maka dapat diambil rumusan masalah, Bagaimana membuat aplikasi bahasa pemrograman Visual Basic 6.0 dalam membantu pengelolaan data layanan kesehatan pada pasien di puskesmas Talang Tinggi?

\section{TINJAUAN PUSTAKA}

\section{Perancangan Sistem}

Pada saat hendak membuat sebuah sistem yang akan digunakan pada suatu perusahaan, setiap pengembang aplikasi diharuskan membuat sebuah rancangan dari sistem yang ingin dibuat. Rancangan ini bertujuan untuk memberi gambaran umum dari sistem yang akan berjalan nantinya kepada setiap stakeholder. Berikut ini terdapat pula beberapa teori mengenai pengertian perancangan sistem.

Mohamad Subhan (2012:109) dalam bukunya yang berjudul Analisa Perancangan Sistem mengungkapkan: "Perancangan adalah proses pengembangan spesifikasi baru berdasarkan rekomendasi hasil analisis sistem".

Perancangan sistem adalah sekumpulan aktivitas yang menggambarkan secara rinci bagaimana sistem akan berjalan. Hal itu bertujuan untuk menghasilkan produk perangkat lunak yang sesuai dengan kebutuhan user. Langkah awal dalam membuat sebuah sistem adalah perancangan dari sistem tersebut. Rancang sistem adalah penentuan proses dan data yang diperlukan oleh sistem baru. Perancangan adalah kegiatan yang memiliki tujuan untuk mendesain sistem baru yang dapat menyelesaikan masalah-masalah yang dihadapi perusahaan yang diperoleh dari pemilihan sistem yang terbaik.

\section{Rekam Medis}

Rekam medis adalah rekaman atau catatan mengenai siapa, apa, mengapa, bilamana, dan bagaimana pelayanan yang diberikan kepada pasien selama masa perawatan, yang memuat pengetahuan mengenai pasien dan pelayanan yang diperoleh serta membuat informasi yang cukup untuk mengidentifikasi pasien, membenarkan diagnosis, dan pengobatan serta merekam hasilnya. (Budi, 2011:3).

Unit rekam medis sebagai salah satu gerbang terdepan dalam pelayanan kesehatan, dapat juga sebagai salah satu ukuran kepuasan pasien dalam menerima pelayanan. Ruang lingkup unit rekam medis mulai dari penerimaan pasien sampai dengan penyajian informasi 
kesehatan. Tugas unit rekam medis mulai dari pengumpulan data, pemrosesan data, dan penyajian informasi kesehatan.

Data yang dikumpulkan berupa data social dan data medis Data social didapatkan ketika pasien mendaftar sebagai pasien, sedangkan data medis didapatkan setelah pasien mendapat pemeriksaan dari tenaga kesehatan.

\section{Puskesmas}

Menurut Permenkes Nomor 75 Tahun 2014 Pusat Kesehatan Masyarakat yang selanjutnya disebut Puskesmas adalah fasilitas pelayanan kesehatan yang menyelenggarakan upaya kesehatan masyarakat dan upaya kesehatan perseorangan tingkat pertama, dengan lebih mengutamakan upaya promotif dan preventif, untuk mencapai derajat kesehatan masyarakat yang setinggi-tingginya di wilayah kerjanya.

Wilayah kerja puskesmas meliputi satu kecamatan atau sebagai dari kecamatan. Faktor kepadatan penduduk, luas daerah, keadaan gigrafi dan keadaan infrastruktur lainnya merupakan bahan pertimbangan dalam menentukan wilayah kerja puskesmas. Sasaran penduduk yang dilayani oleh sebuah puskesmas rata-rata 30.000 penduduk. Untuk perluasan jankawan pelayanan kesehatan maka sederhana yaitu puskesmas pembantu dan puskesmas keliling.

Pelayanan kesehatan yang diberikan di puskesmas adalah pelayanan kesehatan yang meliputi pelayanan pengobatan ( kuratif ), upaya pencegahan ( preventif ), peningkatan kesehatan ( promotif ) yang ditunjukan kepada semua penduduk dan tidak dibedakan jenis dan golongan umur, sejak pembuatan dalam kandungan tuup usia.

\section{Visual Basic 6.0}

Microsoft Visual Basic 6.0 adalah program untuk membuat aplikasi berbasis Microsoft windows secara cepat dan mudah". Visual basic menyediakan tools untuk membuat aplikasi yang sederhana. (Madcoms, 2008).

Visual Basic adalah bahasa pemrograman yang digunakan untuk membuat aplikasi Windows yang berbasis
GUI (Graphical User Interface). Visual Basic menggunakan konsep event-driven programming, yang artinya program menunggu sampai adanya respon dari user berupa event / kejadian tertentu (tombol diklik, menu dipilih, dan sebagainya). Ketika event terdeteksi, event yang berhubungan akan melakukan aksi sesuai dengan kode yang diberikan.

\section{METODOLOGI PENELITIAN}

Pada tahap metodologi penelitian akan diuraikan tentang metode yang dipakai dalam penelitian yang tercakup dalam kerangka kerja penelitian mulai dari mengidentifikasai masalah, menganalisa masalah, menentukan tujuan, mempelajari literatur dan tutorial, teknik pengumpulan data, menganalisa data, pengujian dan implementasi.

\section{ANALISA DAN PERANCANGAN}

1. Analisa Sistem Yang Sedang Berjalan Sebelum melakukan pengembangan terhadap suatu sistem, maka dilakukan analisa sistem yang dipakai di Puskesmas Talang Tinggi yang dilakukan dengan cara mencatat ulang data pasien dan rekam medis pasien dari catatan daftar kunjungan pasien secara manual ke dalam sebuah lembar laporan. Bagian administrasi juga harus membuat laporan pembayaran yang juga dilakukan dengan cara mencatat ulang secara manual dari buku daftar pembayaran pasien. Proses ini dirasakan kurang efektif, dikarenakan petugas Puskesmas seringkali mendapatkan hambatan pada saat pencarian data pasien ketika dibutuhkan kembali. 
2. Analisa sistem Baru

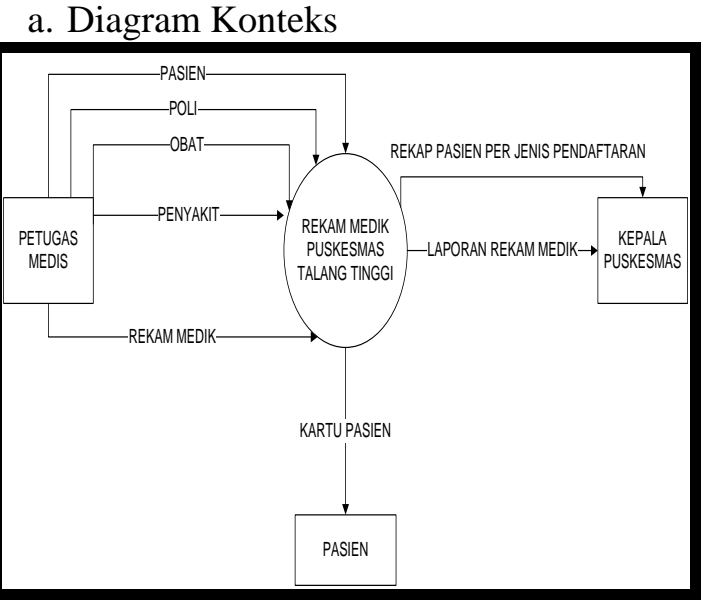

Gambar 1 : Diagram Konteks

b. Data Flow Diagram Level 0

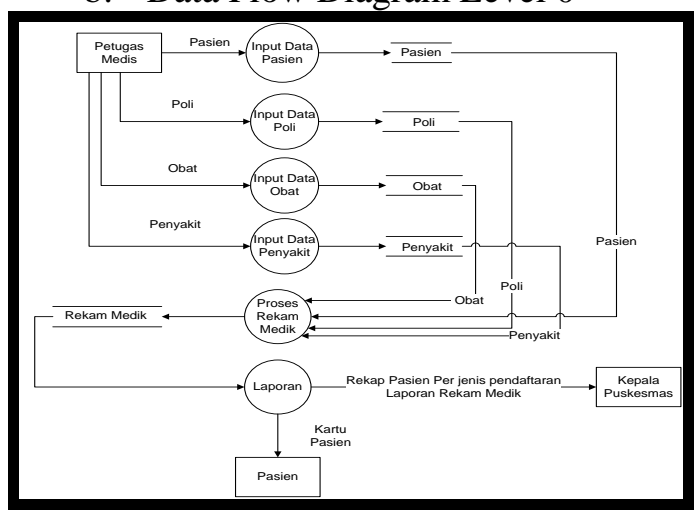

Gambar 2 : DDF Level 0

c. ERD

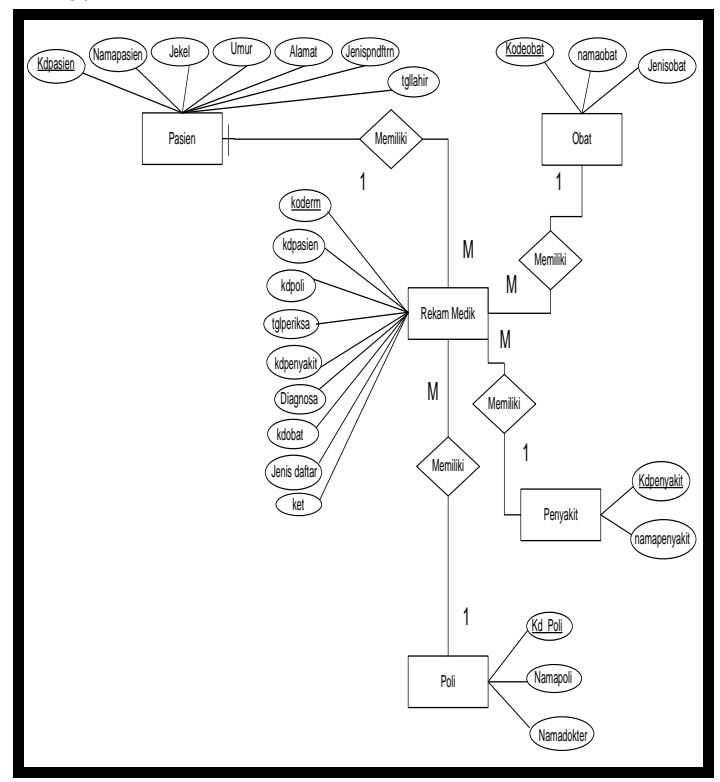

Gambar 3 : Entity Relation Diagram

\section{HASIL DAN PEMBAHASAN}

Dari Hasil dan Analisa sistem dan perancangan sistem maka diperoleh hasil rancangan sistem sebagai berikut :

1. Menu Log In

Tampilan menu log in terdiri dari username, password, yang mana Visual Basic 6.0 menggunakan database Microsoft Acces memanggil data yang telah diinputkan melalui form pada Visual Basic 6.0

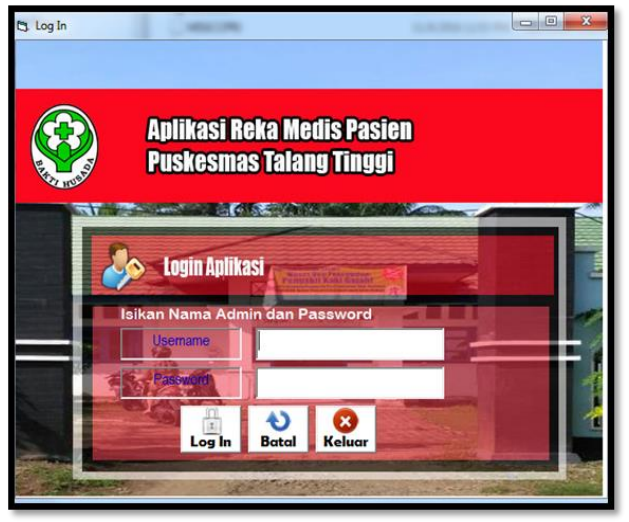

Gambar 4 : Tampilan Form Log In

2. Tampilan Menu Utama

Tampilan menu utama menyajikan sub menu input data, menu proses, menu Laporan dan Keluar seperti gambar berikut:

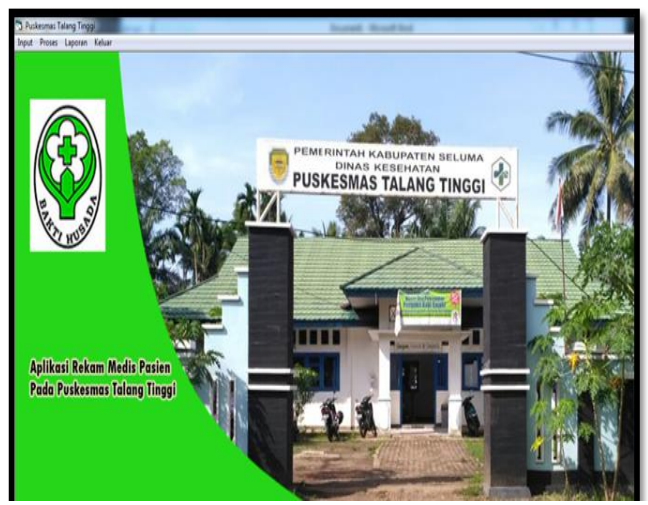

Gambar 5 : Menu Utama 
3. Tampilan Form Jenis Pendaftaran

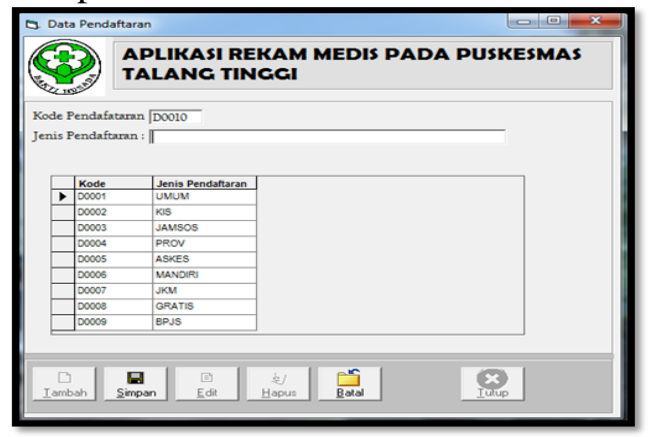

Gambar 6 : Form Jenis Pendaftaran

Pada sub menu ini berfungsi untuk menginput data pengguna, yang terdiri dari tombol proses tambah, simpan, edit dan hapus, batal, dan tutup

4. Tampilan Form Input Data Pasien

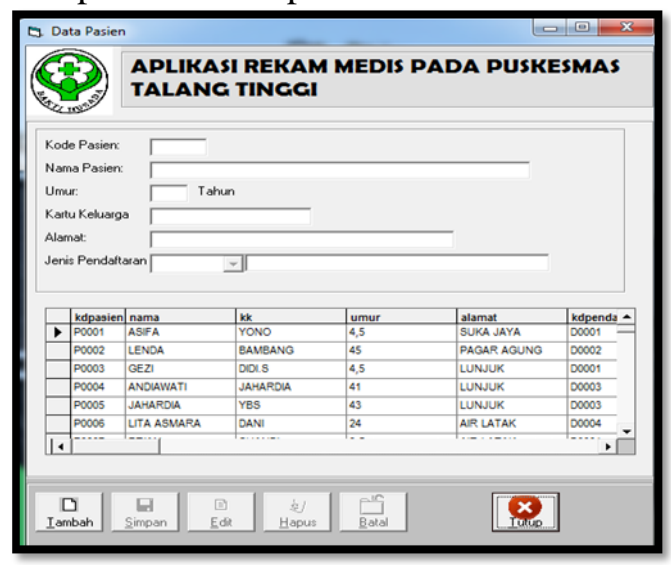

Gambar 7 : Form Input Data Pasien

Pada sub menu ini berfungsi untuk menginput data pasien yang teridiri dari tombol proses untuk tambah, koreksi, simpan, hapus dan keluar.

5. Tampilan Input Data Diagnosa

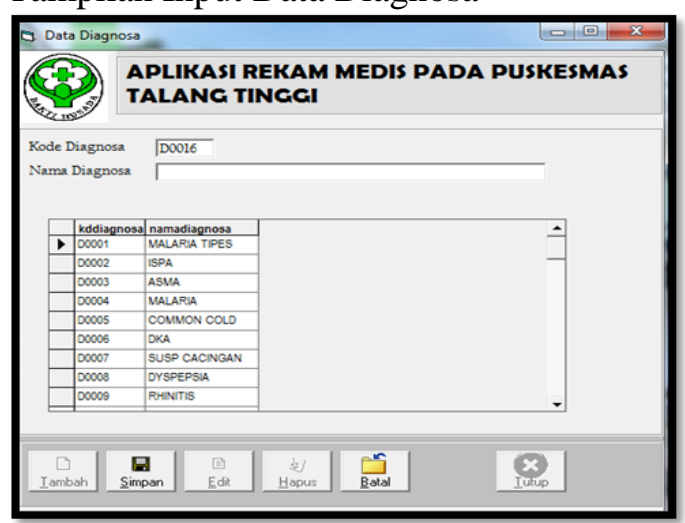

Gambar 8 : Form Input DataDiagnosa
APLIKASI REKAM MEDIS PADA PUSKESMAS TALANG TINGGI

Kode Ther

Kode Therapy
Nama Therapy

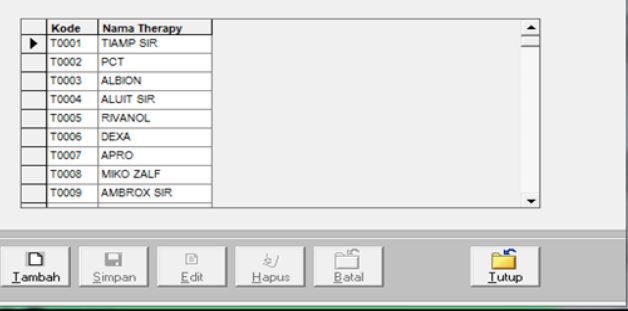

Gambar 9 : Form Input Data Terapi

7. Tampilan Form Proses Rekam Medis

Pada sub menu ini merupakan proses pengolahan data rekam medik yang merupakan proses untuk memperoleh laporan. Pada proses rekam medik yang terdiri dari tombol proses tambah, simpan, tutup dan keluar. Dalam proses ini menghubungkan antara form pasien, form pendaftaran, form diagnosis, form therapy. Yang diolah kemudian disimpan untuk memperoleh laporan yang dibutuhkan.

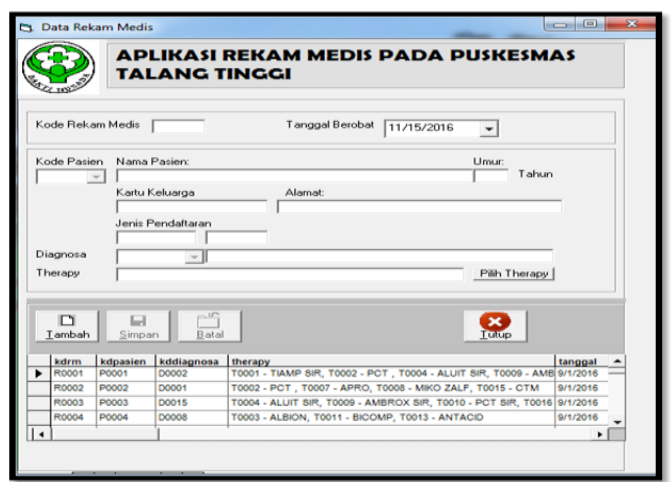

\section{Gambar 10 : Form Proses Pengolahan Data Rekam Medis}

6. Tampilan form input data terapi 
8. Tampilan Form Laporan
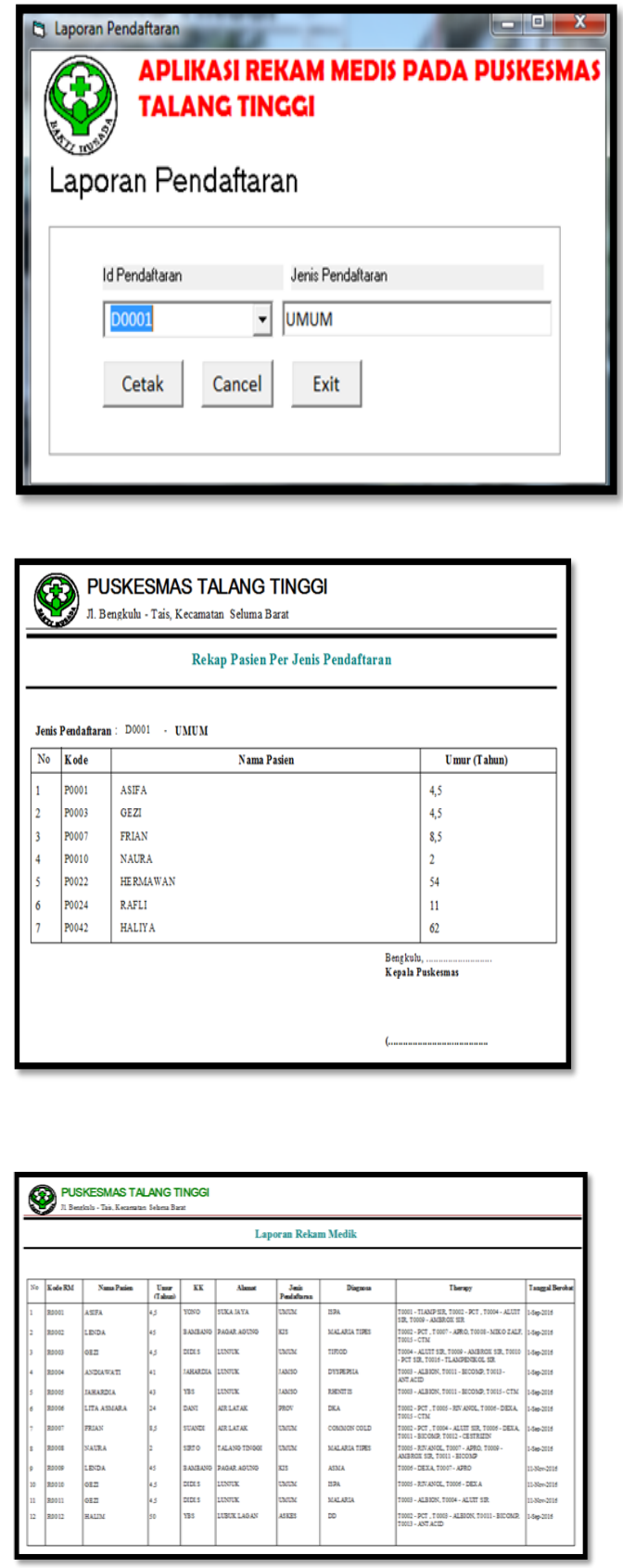

Tampilan Form Cetak Kartu Berobat

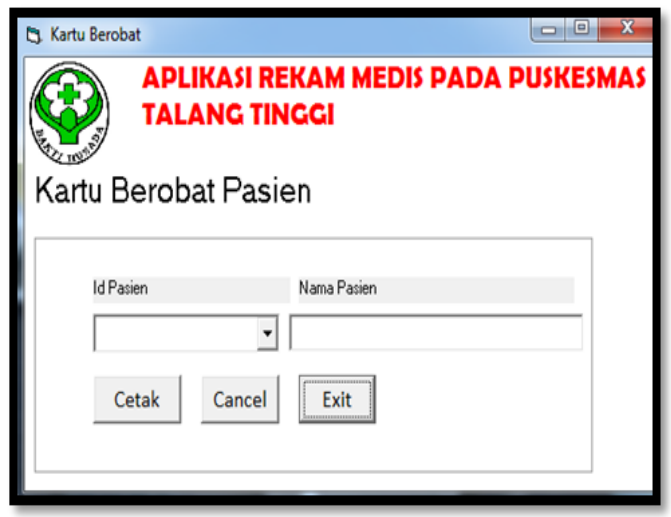

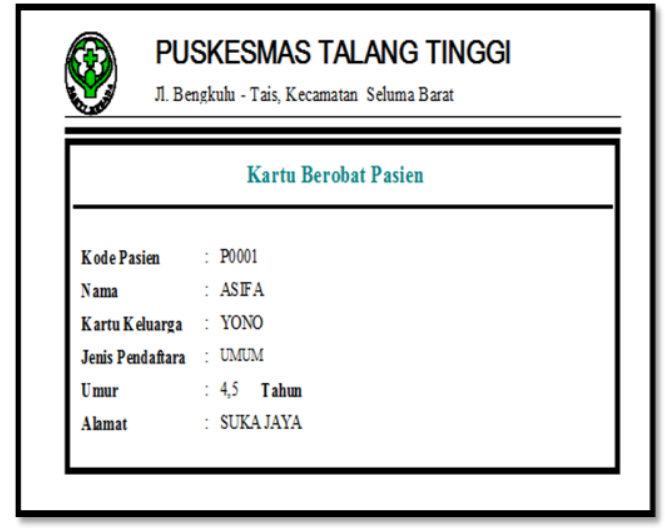

\section{KESIMPULAN}

Dari hasil analisis sistem, pengumpulan data dan perancangan sistem, maka diperoleh kesimpulan sebagai berikut

1. Sistem komputerisasi dalam memberikan pelayanan kesehatan di puskesmas Talang Tunggi dapat meningkatkan mutu pelayanan sehingga kepuasan pasien semakin membaik.

2. Dapat memberikan informasi yang lebih cepat dalam Pengolahan data rekam medis pasien sehingga menghasilkan pelaporan yang bisa menjadi penunjang dalam pengambilan keputusan.

\section{DAFTAR PUSTAKA}

Depkes, RI, 2006. Pedoman Penyelenggaraan dan Prosedur Rekam Medis Rumah Sakit di Indonesia. Jakarta: Direktorat Pelayanan Medik.

Kadir, Abdul, 2003. Pengenalan Sistem Informasi, Andi Offset, Yogyakarta

Madcoms, 2008. Microsoft Visual Basic 6.0 untuk Pemula, Andi Publisher, Yogyakarta.

Mawarni, 2013. Identifikasi Ketidaklengkapan Rekam Medis Pasien Rawat Inap Rumah Sakit Muhammadiyah Lamongan. 
Fakultas Kesehatan Masyarakat,

Universitas Airlangga, Surabaya

Saiful Nur Arif, 2013, Aplikasi Administrasi

Perpustakaan Berbasis Web Smk Swasta

Brigjend Katamso Medan. STMIK

Triguna Dharma

Safitri Citra Budi, 2011, Manajemen Unit Kerja

Rekamedis. Yogyakarta Quantum

Sinergis Media

Subhan, Mohamad. 2012. Analisa Perancangan

Sistem. Jakarta : Lentera Ilmu Cendikia 